University of the District of Columbia School of Law

Digital Commons @ UDC Law

1998

Terry, Race, and Judicial Integrity: The Court and Suppression During the War on Drugs

Jack B. Weinstein

Mae Quinn

Follow this and additional works at: https://digitalcommons.law.udc.edu/fac_journal_articles

Part of the Courts Commons, Criminal Law Commons, and the Food and Drug Law Commons 


\section{St. John's Law Review}

Volume 72

Number 3 Volume 72, Summer-Fall 1998,

Numbers 3-4

\section{Terry, Race, and Judicial Integrity: The Court and Suppression During the War on Drugs}

Hon. Jack B. Weinstein

Mae C. Quinn

Follow this and additional works at: https://scholarship.law.stjohns.edu/lawreview 


\title{
TERRY, RACE, AND JUDICIAL INTEGRITY: THE COURT AND SUPPRESSION DURING THE WAR ON DRUGS
}

\author{
HONORABLE JACK B. WEINSTEIN* \\ MAE C. QUINN**
}

\section{INTRODUCTION}

Thirty years ago the Supreme Court announced the "stop and frisk" rule that has become so much a part of modern criminal jurisprudence. Since then, commentators argue, the liberal and lenient Terry $v$. Ohio ${ }^{1}$ standard has been utilized to justify race-based stops by many law enforcement officers.

In responding to Professor Tracey Maclin's concerns about the Terry decision, we examined the Court's pronouncement as well as its current application. We conclude that while the rules established in Terry are not unacceptable in and of themselves, the way in which the "reasonable articulable suspicion" standard has been used against minority communities during this country's War on Drugs ${ }^{2}$ is disturbing in its inequalities of enforcement. We need to start from the premise that racism in the United States is among our most serious problems, and that the administration of criminal justice reflects the racial and ethnic issues that continue to plague us. ${ }^{3}$ Given this reality, until

- Senior United States District Court Judge, Eastern District of New York.

** Former Law Clerk to the Honorable Jack B. Weinstein.

392 U.S. 1 (1968).

${ }^{2}$ This term was popularized when former President Ronald Reagan declared war on drugs in 1982. See Michael Tonry, Race and the War on Drugs, 1994 U. CHI. LEGAL F. 25, 25 (1994). Since then, the United States government has spent huge sums annually in an attempt to limit drug use and extinguish the drug trade. See id. at 26-27. Commentators assert the war has been ineffective, costly and above all has victimized the poor and minority communities. See $i d$.

${ }^{3}$ See, e.g., Steven A. Holmes, Clinton Panel on Race Urges Variety of Modest Measures, N.Y. TIMES, Sept. 18, 1998, at A1 (reporting Presidential advisory board's opposition to the use of racial profiling by state and federal law-enforcement agencies). 
changes are made in current policing policies, courts must be more sensitive to realities in ensuring that the Fourth Amendment does not give way to our country's fear of drugs. Pressure from those who do not favor the Fourth Amendment is endemic. ${ }^{4}$

\section{TERRY}

Terry set out a basic standard, a guideline for law enforcement and courts. Terry was not incorrect as a matter of law, and it is a valid extension of Fourth Amendment doctrine. The standard is, however, subjectively applied in practice and is sometimes used to justify unfair police conduct.

\section{A. Basic Standard}

Little need be said about the specifics of the Terry standard. Few are unfamiliar with the test it laid down-an officer possessing "specific and articulable facts which, taken together with rational inferences from those facts" ${ }^{\prime 5}$ create the belief that "criminal activity may be afoot" is permitted to conduct an investigatory stop. If the officer has reason to believe that the person he is dealing with may be "armed and presently dangerous," the additional protective step of a Terry pat-down becomes acceptable." An officer's "inchoate and unparticularized suspicion or 'hunch' " will not carry the day. ${ }^{10}$ The question to be asked by courts assessing the propriety of an action premised on Terry is "whether a reasonably prudent man [in the officer's place] ... would be warranted in the belief' held by the particu-

'A recent example of this pressure is illustrative. In United States v. Bayless, 921 F. Supp. 211 (S.D.N.Y. 1996), District Judge Harold Baer reversed his previous decision in which he had suppressed drug evidence seized by New York City police officers. Facing tremendous pressure from the Police Commissioner and Mayor of New York as well as from the Governor and the President, the judge was unfairly charged by some with having had a "change of heart." Don Van Natta, Jr., Under Pressure, Federal Judge Reverses Decision in Drug Case, N.Y. TIMES, Apr. 2, 1996, at A1; see also Stephen B. Bright, Casualties of the War on Crime: Fairness, Reliability and the Credibility of Criminal Justice Systems, 51 U. MIAMI L. REV. 413, 415-16 (1997).

${ }_{5}$ Terry, 392 U.S. at 21.

${ }^{6}$ Id. at 30.

${ }^{7}$ See id. at 22.

${ }^{8} I d$. at 30.

${ }^{9}$ See id. at 30-31.

${ }^{10} \mathrm{Id}$. at 27. 
lar officer. ${ }^{11}$

\section{B. As a Matter of Law}

It has been argued by Professor Tracey Maclin and others that the Court made the wrong decision in Terry by providing law enforcement agents with a powerful method for circumventing the Fourth Amendment's explicit warrant requirement. ${ }^{12}$

It had been understood, before Terry, that only very limited situations permitted warrantless intrusions upon a person's privacy. Valid consent obtained from the person whose privacy interest was at stake as well as exigent circumstances were among the recognized exceptions. ${ }^{13}$ Nevertheless, the reality is that police encounters on the street "are incredibly rich in diversity ... rang[ing] from wholly friendly exchanges of pleasantries or mutually useful information to hostile confrontations of armed men involving arrests, or injuries, or loss of life."14 Sometimes splitsecond responses are required by law enforcement agents. The dangers of a mistake led the Court to the conclusion that greater discretion should be vested in the officer on the beat.

Some opponents of the Terry standard have argued that, because the Fourth Amendment makes no mention of "particularized suspicion" permitting investigative stops without probable cause, such stops are violative of the Constitution. ${ }^{15}$ This argument is not persuasive. The Constitution is silent as to a number of well-recognized rules, including those relating to consent and exigent circumstances under the Fourth Amendment and even to the rule on exclusion of wrongfully obtained evidence. Few, however, would argue that these limiting doctrines are not useful and necessary if meaningful policing and protection of the public is to take place.

Some of the same commentators who believe Terry's rule is

${ }_{11}^{11} I d$.

${ }^{12}$ See Tracey Maclin, Terry v. Ohio's Fourth Amendment Legacy: Black Men and Police Discretion, 72 ST. JOHN's L. REV. 1271 (1998).

${ }^{13}$ See, e.g., Ker v. California, 374 U.S. 23 (1963) (recognizing exigent circumstances supported warrantless entry); Davis v. United States, 328 U.S. 582 (1946) (finding valid consent for search).

${ }^{14}$ Terry, 392 U.S. at 13.

${ }^{15} I d$. (Douglas, J., dissenting) ("Until the Fourth Amendment . . . is rewritten, the person and the effects of the individual are beyond the reach of all government agencies until there are reasonable grounds to believe (probable cause) that a criminal venture has been launched or is about to be launched."). 
without constitutional justification seem untroubled by the idea of premising warrantless stops upon mere probable cause and often favorably tout the requirements of Miranda $v$. Arizona. ${ }^{16}$ Both of these doctrines, however, are conspicuously absent from the plain words of our Constitution. Moreover, the probable cause standard is as capable of manipulation and abuse as is that of "reasonable, articulable suspicion."17

Professor Maclin suggests that the Court should have handled the Terry decision more like the case of Miranda, which "adopted a rule that sought to counteract some ... structural defects in the system."18 While on its face Miranda seems more defendant-oriented than does Terry, its application, as was recently noted by the New York Times, has not been without problems. ${ }^{19}$

Common sense and reality come into play when establishing the contours of the Fourth Amendment. ${ }^{20}$ Thus, in light of the investigative needs of, and dangers faced by, officers in the line of duty, the requirements of Terry, when rationally and reasonably applied in good faith, are not improper extensions of Fourth Amendment doctrine. Terry was not wrongly decided. To think that it could have been decided otherwise at that time or at any other time mistakes the nature of the Court and the nature of our problems. Keep in mind that two members of the Court, Justice Thurgood Marshall and Chief Justice Earl Warren, had extensive experience with the problems of policeminority relations. Chief Justice Warren authored the Terry opinion for the Court, and Justice Marshall did not even write a separate concurrence. Although he may have had qualms about it, Justice Marshall went along with the decision as one that was arguably inevitable in expressing what was then happening in the country and which might perhaps improve the situation for minorities somewhat by exposing this "low visibility" police

${ }^{16} 384$ U.S. 436 (1966).

${ }^{17}$ Cf. Sheri Lynn Johnson, Race and the Decision To Detain a Suspect, 93 YALE L.J. 214, 214-15 ("Both concepts [of probable cause and reasonable suspicion] focus on the aggregate information available to the police and stress the uniqueness of each constellation of facts. This focus has allowed the Court and commentators to neglect the question of whether some facts are impermissible constituents of that constellation.").

${ }^{18}$ Maclin, supra note 12.

${ }^{19}$ See, e.g., Jan Hoffman, Police Refine Methods So Potent, Even the Innocent Have Confessed, N.Y. TIMES, Mar. 30, 1998, at A1; Jan Hoffman, Police Tactics Chipping Away at Suspects' Rights, N.Y. TIMES, Mar. 29, 1998, at A1.

${ }_{26}$ See generally LAURENCE H. TRIBE, CONSTITUTIONAL ChOICES (1985). 
practice for what it was and by providing at least peripheral controls.

Unfortunately, it seems to us that the stop-and-frisk rules announced in Terry and subsequent cases have had little or no impact on the racial problems in the administration of justice.

\section{When Fact and Theory Collide}

Stating that creation of the Terry stop standard was appropriate is not the same as concluding as a factual matter that the officer in Terry was justified in his course of conduct. In view of Fourth Amendment requirements of specificity of suspicion, quite the opposite seems true. The officer saw two men he did not know outside of a store. ${ }^{21}$ They walked back and forth a number of times while looking into the shop's window. ${ }^{22}$ A third man approached. ${ }^{23}$ According to the opinion, based upon these activities the officer became "thoroughly suspicious," thinking that the men may have been planning a robbery. ${ }^{24}$ From this "hypothesis," the officer arrived at the further conclusion that the crime being planned involved weapons and that the men he saw outside of the store were likely armed. ${ }^{25} \mathrm{He}$, therefore, decided to pat down defendant Terry's clothing, leading to the discovery of a gun. ${ }^{26}$ The officer was right in this instance, but in how many would he have been wrong?

As was noted by Professor Maclin in excerpting portions of testimony from the actual suppression hearing in Terry, the suspicion generated by the defendants' activity was "dubious."27 The officer had never encountered this sort of behavior in connection with a robbery, had not previously observed anyone that he thought might "pull a stick-up," and possessed no specific inculpatory information with regard to the men he observed outside of the store. His less than "expert" opinion, leading to his accosting the individuals, can be summed up with his statement "I didn't like their actions . . . they didn't look right to me at the time." ${ }^{28}$

\footnotetext{
${ }^{21}$ See Terry, 392 U.S. at 5-6.

${ }^{22}$ See id.

${ }^{23}$ See id. at 6.

${ }^{24} I d$.

${ }^{25} I d$. at 28.

${ }^{28}$ See id.

${ }^{27}$ Maclin, supra note 12.

${ }^{28}$ Terry, 392 U.S. at 5.
} 


\section{Harassment, Race, and the Vital Function of Suppression}

While it is the case that the required showing of what is necessary to stop citizens on the street without prior permission of a court was undoubtedly lowered by Terry, the police were not given carte blanche. Discretion is not by itself a bad thing. It is unchecked and unbalanced and untrained discretion that leads to harmful results. Along these lines, the Court's opinion addressed the important issue of investigative stops "undertaken simply as an act of harassment." ${ }^{\text {29 }}$

In seeming counterbalance to the grant of greater police power, the Court took great pains to emphasize the role of trial courts in administering the Fourth Amendment. First, because the Amendment's "major thrust" is one of deterrence, a court's exclusion of evidence was characterized as "a principal mode of discouraging lawless police conduct." ${ }^{30}$ Second, and perhaps more important, it was noted that as a matter of "judicial integrity," courts are not to be "made party to lawless invasions of the constitutional rights of citizens by permitting unhindered governmental use of the fruits of such invasions."

The Court clearly embraced the exclusionary rule as a tool to be used to combat abuses of the new standard:

Under our decision, courts still retain their traditional responsibility to guard against police conduct which is overbearing or harassing, or which trenches upon personal security without the objective evidentiary justification which the Constitution requires. When such conduct is identified, it must be condemned by the judiciary and its fruits must be excluded from evidence in criminal trials. ${ }^{32}$

Active policing of the police by trial courts was noted as serving a "vital function." 33

As definitive as was this message from the Court, another more mixed message was sent by the decision. Despite prompting courts to continue to act as guardians against improper police action, the limitations of the exclusionary rule as a protective device were highlighted: ${ }^{34}$

\footnotetext{
${ }^{29}$ Id. at 28.

${ }^{30} I d$. at 12 .

31 . at 12-13.

${ }^{32}$ Id. at 15 .

${ }^{33} I d$. at 12.

${ }^{34}$ See id. at 13.
} 
The wholesale harassment by certain elements of the police community, of which minority groups, particularly Negroes, frequently complain, will not be stopped by the exclusion of any evidence from any criminal trial.... [R]igid and unthinking application of the exclusionary rule, in futile protest against practices which it can never be used effectively to control, may exact a high toll in human injury and frustration of efforts to prevent crime. ${ }^{35}$

The Court was aware of the possibility that police stop and frisks could be used to maintain inappropriate power over particular groups. Baseless stops, it acknowledged, would exacerbate "police-community tensions" generally, and in minority communities in particular. ${ }^{36}$ Notably, however, the Terry opinion did not mention the race of the men stopped for standing outside of the store, nor the race of the seizing officer.

\section{BEYOND TERRY}

Terry recognized that allowing police stop-and-frisks could lead to excessive control over minorities. The drug war has been characterized by frequent race-based policing, impacting minority groups the hardest. While some after-the-fact remedies exist for such groups, the solution lies in better police recruitment and training and, in the long term, developing in all of society greater inter-racial respect.

\section{A. Communities Under Siege}

Professor Maclin has pointed out that the behavior of the officer in Terry "typified police conduct in the 1960s" given the unrest of the time and the hyper-vigilance of officers in search of armed and dangerous persons. ${ }^{37}$ Certainly, riots and uprisings and what appeared to some to be the unraveling of the social fabric had created a good deal of fear and distrust. ${ }^{38}$

\footnotetext{
${ }^{35}$ Id. at $14-15$ (footnote omitted).

${ }^{36}$ Id. at 14-15, n.11. The Court explained:

[Frisking] cannot help but be a severely exacerbating factor in policecommunity tensions. This is particularly true in situations where the stop and frisk of youths or minority group members is motivated by the officers' perceived need to maintain the power image of the beat officer, an aim sometimes accomplished by humiliating anyone who attempts to undermine police control of the streets.

Id. (internal quotation marks omitted).

${ }_{37}^{37}$ Maclin, supra note 12.

${ }^{38}$ See STEPHAN THERNSTROM \& ABIgAIL THERNSTROM, AMERICA IN BLACK AND
} 
Thirty years later the social and economic situation of minorities is improved, but still unstable. To a large degree, the thinking and acting of the sixties continues to shape policing in this country, particularly in the War on Drugs.

In our nation's attempt to deal with the problem of drug abuse and trafficking, law enforcement efforts have been greatly intensified. ${ }^{39}$ The amount of government money spent on policing and incarceration has soared. ${ }^{40}$ As in the sixties, our minority communities have borne the brunt of this crack down. ${ }^{41}$ Disparate sentencing laws creating a 100 to 1 ratio for crack versus powder cocaine, as well as harsh mandatory minimums sending young people away to prison for decades have decimated some peer groups in some of our inner cities. ${ }^{42}$ Overwhelmingly African Americans and Hispanics are targeted by anti-drug law enforcement efforts. ${ }^{43}$ As a result, many people are intimidated and abused.

Consider the example of a recent "checkpoint" set up in Bronx, New York, by federal law enforcement agents in an attempt to "stem the tide of a . . rise in drug activity and drive-by shootings in the area." By the FBI's own account, the "Watson Avenue Special Operation" program involved:

[T] he cordoning of an 8 block area and the use of vehicle checkpoints to screen all individuals attempting to drive into the area. Officers operating the checkpoints were instructed to stop every vehicle entering the area and determine the driver's association with the neighborhood. Only residents, drivers of commercial vehicles, drivers of vehicles dropping off small children, or visitors to the lo-

WHITE: ONE NATION, INDIVISIBLE 158-70 (1997) (recounting the "long hot summers" of the sixties involving riots throughout the country).

${ }^{39}$ See THE REAL WAR ON CRIME 1-2 (Steven R. Donziger ed., 1996); see also Tonry, supra note 2, at 25 ("American prison and jail populations tripled between 1980 and 1993, primarily due to increased numbers of drug convictions and longer sentences for drug offenders.") (footnotes omitted).

${ }^{40}$ See REAL WAR, supra note 39, at 1-2, 31, 47-54.

${ }^{41}$ See generally Tonry, supra note 2.

${ }^{42}$ See generally Jack B. Weinstein \& Mae C. Quinn, Some Reflections on the Federal Judicial Role During the War on Drugs, (prepared for the International Conference on Criminal Law at the Queen's University of Belfast) (forthcoming).

${ }^{43}$ See, e.g., STEVEN B. DUKE \& ALBERT C. GROSS, AMERICA'S LONGEST WAR 12526 (1994) (detailing ways in which minority groups have been targeted by drug enforcement efforts).

${ }^{4}$ Kimberly A. Crawford, Checkpoints: Fourth Amendment Implications of Limiting Access to High Crime Areas, FBI L. ENFORCEMENT BULL., Mar. 1998, at 27. 
cal church were permitted to enter the area.... The checkpoint was operated on a random basis, 6 hours a day, 3 days a week, for a period of 3 weeks. ${ }^{45}$

At the checkpoint a retired African-American police officer, Winfred Maxwell, attempting to visit his daughter who lived in the area, was stopped and asked for identification. ${ }^{46}$ His encounter with police that evening led to Maxwell's arrest and criminal prosecution for assault, disorderly conduct, resisting arrest, and harassment. ${ }^{47}$ After acquittal he filed a lawsuit asserting civil rights claims, based in part, upon a claimed violation of his Fourth Amendment rights. ${ }^{48}$

The district court found that the Fourth Amendment issue was sufficiently ambiguous in the civil action as to warrant jury determination and denied the city's request for summary judgment. ${ }^{49}$ A panel of the United States Court of Appeals for the Second Circuit reversed, with Judge Oakes dissenting. ${ }^{50}$ While the claim in Maxwell dealt with the reasonableness of the checkpoint operation, for which no probable cause or reasonable articulable suspicion is necessary, it is a vivid example of the kind of policing with which predominantly minority communities must contend during the Drug War. It is doubtful that such an invasive "operation" would be instituted or maintained in nonminority populated areas.

\section{B. Multi-Class Society; Disparate Access to Justice}

Ours is a multi-tiered, multi-class society. ${ }^{51}$ Differing groups

${ }^{45} I d$. (footnote omitted).

${ }^{46}$ See id. at 28.

${ }^{47}$ See id.

${ }^{48}$ See Maxwell v. City of New York, 102 F.3d 664 (2d Cir. 1996), cert. denied, 118 S. Ct. 57 (1997). Maxwell alleged that even though he identified himself to police as a retired officer he was ordered out of his car, flipped to the ground, and beaten. See id. at 666 . The only issue dealt with on appeal was the trial court's denial of summary judgment as to the Fourth Amendment-based civil rights claim. See id. Mr. Maxwell also alleged other claims including excessive force and illegal detention. See id. At the time of the writing of this article, these claims are still pending in the Southern District of New York before Magistrate Judge Naomi Reice Buchwald.

${ }^{49}$ See id. at 666-67.

${ }^{50}$ See id. at 668, 668-71. Judge Oakes's dissent acutely points out that the Second Circuit's decision in reversing Judge Mukasey "is essentially giving the New York City Police Department a judicial blank check to conduct similar 'special operations." "Id. at 671 .

${ }^{51}$ See KeVIN PhILlips, POLITICS OF THE RICH AND POOR 3-31 (1990); see also, 
have been provided with differing protections and privileges. Access to, as well as quality of, medical services fluctuate depending upon status. Inner-city public schools, when compared to suburban private institutions, are often inferior. And, as evidenced by the "checkpoint" set up in the Bronx, the law enforcement system reflects disparate treatment based upon race and class.

A post-World War II Warren Court tried to equalize the law ${ }^{52}$ by moving to eliminate segregated schools, ${ }^{53}$ enforcing equal votirg rights, ${ }^{54}$ and attempting to create fairness in the administration of criminal justice. ${ }^{55}$ Despite these efforts, our world still lacks fundamental fairness for all, and backsliding continues. $^{56}$

\section{Race-Based Traffic Stops}

Disparate treatment often manifests itself through racebased traffic stops and drug courier investigations, two tools of the Drug War's soldiers. Cars are frequently stopped based upon the race of the driver of the vehicle. ${ }^{57}$ On one stretch of highway in Maryland, the total number of African-American drivers stopped comprised fifty-seven to eighty percent of the total number subjected to such intrusions. ${ }^{58}$ In Orlando, Florida, almost seventy percent of those drivers stopped along I-95 were minori-

Randall S. Susskind, Note, Race, Reasonable Articulable Suspicion, and Seizure, 31 AM. CRIM. L. REV. 327, 349 (1994) (commenting that failure to enforce the reasonable articulable suspicion standard "will perpetuate a dual racially based system in which minority defendants receive less Fourth Amendment protection than their white counterparts").

${ }^{52}$ See CASS R. SUNSTEIN, THE PARTIAI CONSTITUTION 1 (1993). Sunstein notes:

"In the last generation, the terms of American constitutional law were set by the Warren Court and its successor ... An aggressive Supreme Court, acting on the basis of new ideas about civil rights and civil liberties, tried to bring about significant social change in the name of the Constitution." Id.; see generally ED CRAY, CHIEF JUSTICE: A BIOGRAPHY OF EARL WARREN (1997).

${ }_{53}$ See Brown v. Board of Education, 347 U.S. 483 (1954).

${ }^{54}$ See South Carolina v. Katzenbach, 383 U.S. 301 (1966).

${ }^{55}$ See Gideon v. Wainwright, 372 U.S. 335 (1963).

${ }^{56}$ See Hopwood v. Texas, 78 F.3d 932 (5th Cir. 1996).

${ }^{57}$ See, e.g., Angela J. Davis, Race, Cops, and Traffic Stops, 51 U. MIAMI L. REV. 425 (1997); David Rudovsky, The Impact of the War on Drugs on Procedural Fairness and Racial Equality, 1994 U. CHI. LEGAL F. 237; Susskind, supra note 51.

${ }^{58}$ See Paul W. Valentine, Md. State Police Accused of Duplicity, WASH. POST, Dec. 5, 1997 at D4 (citing statistics submitted to federal court by the ACLU in support of a class-action law suit). 
ties. $^{59}$ On a portion of the New Jersey Turnpike it is said that African-American motorists are stopped five times more often than white drivers. "DWH" and "DWB," otherwise known as "driving while Hispanic" and "driving while Black" respectively, are phrases describing such traffic stops. ${ }^{61}$

\section{Drug Courier Profile}

The "drug courier profile" is also commonly relied upon at border crossings, airports, bus stations and train depots by law enforcement officers stopping minorities under the guise of detecting illegal drugs. ${ }^{62}$ It is difficult to say what the "profile" is, since it appears to change based upon the needs of the moment. ${ }^{63}$ It has been pointed out that in some instances Latinos are said to be more likely to be drug couriers, while at other times it has been opined that the predominant number of drug mules are African-American females. ${ }^{64}$ Characteristics that pertain to many non-minority travelers, such as paying for tickets with cash, departing from "source cities," and traveling without luggage, suddenly take on great import when applied to persons of color. ${ }^{65}$

\section{Results and Remedies for Drug War Policing}

The net effect of such drug war tactics is that many minority

${ }^{59}$ See Jeff Brazil \& Steve Berry, Color of Driver is Key to Stops in I-95 Videos; The Tapes Show that Most Stops and Searches by Volusia County's Drug Squad Involve Minorities, ORLANDO SENTINEL TRIB., Aug. 23, 1992 at A1, available in 1992 WL 466820 . This result was based upon video tapes made by police of over 1000 traffic stops. See id.

${ }^{60}$ See Greg Williams, Selective Targeting in Law Enforcement, 10 NAT'L BAR ASS'N. MAG. 18, 19 (1996).

${ }^{61}$ See, e.g., Jennifer A. Larrabee, Note, "DWB (Driving While Black)" and Equal Protection: The Realities of an Unconstitutional Police Practice, 6 J.L. \& PoL'Y 291 (1997).

${ }^{62}$ See Mark J. Kadish, The Drug Courier Profile: In Planes, Trains, and Automobiles; and Now in the Jury Box, 46 AM. U. L. REV. 747 (1997); cf. Sam Howe Verhovek, Trade Pact Brings Drug Searches and Traffic Jams, N.Y. TMMES, Mar. 20, 1998, at A12.

${ }^{6}$ See Kadish, supra note 62, at 748.

${ }^{64}$ See Johnson, supra note 17, at 240.

${ }^{65}$ See United States v. Hooper, 935 F.2d 484, 499-500 (2d Cir. 1991) (Pratt, J., dissenting). Judge Pratt wisely noted that the "drug courier profile' is . . . laughable, [] because it is so fluid that it can be used to justify designating anyone a potential drug courier if the DEA agents so choose." Id. at 499; see also Rudovsky, supra note 57, 244-45 ("Profiles encourage stops based on non-criminal behavior and personal appearance and include characteristics shared by a large number of innocent people."). 
communities feel a sense of vulnerability, generating a distrust of the very people who are assigned to protect them from crime. ${ }^{66}$ A disaffection for law enforcement, and government in general, sometimes results. ${ }^{67}$ Police in some areas are viewed as the enemy, even by the law-abiding. ${ }^{68}$

What can be done to remedy the situation as it now exists? The law makes some remedies available. Individuals who believe that they have been improperly stopped and harassed by police can file federal civil rights claims. ${ }^{69}$ These lawsuits are costly, however, and not all attorneys will take such cases on a contingency basis. Such suits require many years of depositions and court appearances-often with disappointing results, given the difficult standards. ${ }^{70}$ Nevertheless, bringing a civil action might encourage injunctive relief by way of settlement. ${ }^{71}$

Professor Maclin quoted a retired Detroit police officer as stating "I would estimate-and this I have heard in the station also- that if you stop and search 50 Negroes and you get one good arrest out of it, that's a good percentage; its a good day's work." ${ }^{72}$ Given the power in numbers, perhaps more civil rights class action suits should be brought by those aggrieved in such situations. $^{73}$

${ }^{66}$ See Davis, supra note 57 , at 443 (stating that a loss of "the integrity of the legal process and the trust of all citizens" has resulted from discriminatory criminal laws).

${ }^{67}$ See id. at 442 ("When people of color experience injustices that are tolerated and even sanctioned by courts and other criminal justice officials, they develop distrust and disrespect for the justice system."); cf. Jack B. Weinstein, The Many Dimensions of Jury Nullification, 81 JUDICATURE 168, 171 (1998) (noting that jury distrust of law enforcement officers based upon their own contacts with police may lead to jury nullification).

${ }^{68}$ Cf. RANDAll KeNNEDy, RACE, CRIME, AND THE LAW 157 (1997) (explaining that one of the costs of race-based stops is that they lead to resentment by those stopped, defensiveness on the part of the police, and may "generate needless arrests, and occasionally spark violence").

${ }^{63}$ See, e.g., 42 U.S.C. \& 1983 (1979).

${ }^{70}$ Cf. David E. Rovella, States are New Venue to Sue Cops, NAT'L. L.J., Apr. 20, 1998, at 1 (observing that states, "[r] eacting to two decades of court rulings limiting federal suits" are using their own constitutions to provide greater rights to those aggrieved by police misconduct).

${ }^{71}$ An example of such injunctive relief can be seen in the case brought by Attorney Robert L. Wilkins in Maryland. See Judge Tells Md. Police to Provide Stop Details; ACLU Seeks Information on Bias in Roadside Searches, BALT. SUN, Apr. 12, 1997 , at $2 \mathrm{~B}$, available in 1997 WL 5506488.

72 Maclin, supra note 12.

${ }^{73}$ See, e.g., Whitfield v. Board of County Commissioners, 837 F. Supp. 338 (D. Colo. 1993). But see Durgin v. De La Vina, 174 F.R.D. 469 (D. Ariz. 1997). 
Short of instituting a court action, those aggrieved can lodge complaints with local civilian review boards. These entities were established so that persons independent of the police themselves could oversee police behavior and advise when disciplinary action should be taken. ${ }^{74}$ While it has been suggested that such organizations should be more regularly utilized, ${ }^{75}$ their current efficacy is questionable given their restricted power. ${ }^{76}$ The "slap on the wrist" of fines and other administrative penalties is of limited value in deterring police abuses.

Last year in New York City, following the alleged brutal attack on Abner Louima by members of the New York City police force, Mayor Rudolph W. Guiliani appointed a Task Force on Police/Community Relations, to propose steps to be taken to improve police/community relations. ${ }^{\text {" }}$ Not long ago, the Task Force issued a report recommending improvements. The report suggests that new officers be more closely screened, additional training be given, and that police personnel cooperate more fully with the city's Civilian Complaint Review Board. ${ }^{78}$

Three members of the Task Force dissented from the majority's report, calling it a "whitewash" and condemning it for failing to conduct a thorough analysis of the problem. ${ }^{79}$ The dissenters issued their own report entitled "Deflecting Blame," accusing Mayor Guiliani of using the Task Force as an election year ploy but failing to fully address the issue of harassment and brutality at the hands of the police. ${ }^{80}$

\footnotetext{
${ }^{74}$ See Sean Hecker, Race and Pretextual Traffic Stops: An Expanded Role for Civilian Review Boards, 28 COLUM. HUM. RTS. L. REV. 551, 600 (1997).

${ }_{75}^{75}$ See id. at 600-04.

${ }^{76}$ See David Kocieniewski, Mayor to Raise Pay of Officers on City Beats, N.Y. TIMES, Mar. 26, 1998, at B1 (reporting that New York City's Task Force on Police/Community Relations found that the poor quality of Civilian Complaint Review Board investigations was based upon lack of support from police); see also Commission to Combat Police Corruption, City of New York, Third Annual Report of the Commission 8-12 (Richard J. Davis, Chair, Aug. 1998).

${ }^{7}$ See Dan Barry, Officer Charged in Man's Torture at Station House, N.Y. TIMES, Aug. 14, 1997, at A1 (reporting incident involving a 25-year-old police officer who was charged with assaulting and brutalizing a Haitian immigrant in a Brooklyn station house bathroom); Bob Herbert, One More Police Victim, N.Y. TIMES, Aug. 14, 1997, at A31 (describing the alleged "barbaric behavior" by New York City police); David Kocieniewski, Plan is Seen for New Class of Officers, N.Y. TTMES, Mar. 24, 1998, at B5 (describing finalization of task force's report, which was the final phase of a police department appraisal that began with the Louima attack).
See Kocieniewski, supra note 76, at B1.
${ }^{79}$ See id.
${ }^{80}$ See id. 
Better training of our police force is essential if officers are to be sensitized to the problems. Race-based policing is not acceptable. Comprehensive psychological and other tests would be useful in rooting out those unlikely to interact properly with all members of our communities.

Until broad-based transformation occurs, courts will likely continue to be faced with a number of officers who oppress, harass, or intimidate persons of color. In criminal cases courts should act whenever race is used as a proxy for suspicion, despite the seeming equivocation by the Court in Terry. Jurists must hold firm to the notion that the suspicion articulated must be reasonable. Skin color should not be treated as an acceptable basis for a Terry stop.

\section{Prevarication}

Thirty years after Terry and undoubtedly thousands of suppression hearings later, few officers are naive enough to admit in court that race in fact did play a role in their decision-making. Commentators have suggested that officers often engage in "testilying" and shading of their testimony to avoid having evidence suppressed by the court. ${ }^{81}$

Procedures at suppression hearings are looser than those at criminal trials. The government is given a great deal of leeway. Opinion testimony by the officer is admissible, as is most hearsay. Courts, as gatekeepers to expert testimony, must be vigilant. ${ }^{82}$ The officer in Terry may have been on the force for almost thirty years, but that in and of itself should not have allowed him to opine that the men he seized seemed like daytime robbers.

As Professor Maclin has pointed out, it has become common for courts to credit police testimony in search and seizure cases without looking behind what is actually said. ${ }^{83}$ The officers'

${ }^{81}$ See Morgan Cloud, Judges, "Testilying," and the Constitution, 69 S. CAL. L. REV. 1341, 1352 (1996) (noting that police perjury often occurs at suppression hearings); Christopher Slobogin, Testilying: Police Perjury and What to Do About It, 67 U. COLO. L. REV. 1037, 1040 (1996) ("[L]ying to evade the consequences of the exclusionary rule-is so common and so accepted in some jurisdictions that the police themselves have come up with a name for it: 'testilying.' ").

${ }^{82}$ See Daubert v. Merrell Dow Pharm., Inc., 509 U.S. 579 (1993) (holding that expert opinion is admissible only when the judge deems it relevant and based on reliable methodology, although such methodology need not be generally accepted).

${ }^{83}$ See Maclin, supra note 12. 
credibility must be weighed and assessed.

Whren v. United States ${ }^{84}$ was decided in 1996. It raised the issue of the propriety of pretextual stops-when an officer has subjective motivations for a stop other than those articulated-in particular, race. ${ }^{85}$ Whren unanimously rejected pretext as a ground for suppression of evidence under the Fourth Amendment, noting that such race-based claims should be raised instead under the Equal Protection Clause. ${ }^{86}$ Yet, Whren approved a failure to suppress based upon the officers' somewhat dubious rationale for the traffic stop in question. The signal sent by the Court was one of support for the police despite situational ambiguities.

Truth is still important. Could the officer really have seen what he claims he saw? Does what the officer says make sense in light of usual police practice? Does the story fit together? Credibility must be demonstrated, particularly since the government bears the burden of proof.

\section{E. Vital Function of the Judiciary at Work}

Recently, in the case of United States $v$. Restrepo, ${ }^{87}$ the court found that an officer's proffered reason for conducting a traffic stop was not credible. In that case, a Memphis, Tennessee police officer pulled over a Cadillac with California plates to purportedly conduct a traffic stop. ${ }^{88}$ He found sixty, one-kilogram bricks of cocaine concealed in the skin of the vehicle. ${ }^{89}$ The driver of the car, Jose Guevara, was a dark-complected Latino male. ${ }^{90}$ In the car with him were his eleven-year-old son, Rodolfo, who was sitting in the front seat, and his wife, with two younger children, sitting in the back seat. ${ }^{91}$

The officer in the case testified that defendant had been traveling at sixty-five miles per hour in a fifty-five miles per

\footnotetext{
517 U.S. 806 (1996).

${ }^{85}$ See id. at 810-11.

${ }^{86}$ See id. at 813 ("Subjective intentions play no role in ordinary, probable-cause Fourth Amendment analysis."). Beyond the scope of this paper is the suggestion by the Court that the Equal Protection Clause affords a viable remedy for race-based stops.

890 F. Supp. 180 (E.D.N.Y. 1995) (Weinstein, J.).

${ }^{8}$ See id. at 186.

See id. at 188.

${ }^{90}$ See id. at 186.

${ }^{9 t}$ See id.
} 
hour zone. ${ }^{92}$ He did not issue a traffic citation for defendant's alleged speeding, but did provide him with a "traffic courtesy warning" stating that defendant was traveling above the speed limit. ${ }^{93}$

Defendant Guevara, with the aid of an interpreter, testified that he was driving slowly at the time he was stopped because he was looking for a place for his family to have breakfast. ${ }^{94}$ This was confirmed by Rodolfo. ${ }^{95}$ The defendant further confessed to the court that he was purposely driving under the speed limit because, knowing that he was carrying drugs in his vehicle, he did not want to attract the attention of police. ${ }^{96}$

Rodolfo, the young boy, acted as an interpreter between his father and the officer. ${ }^{97}$ Both the child's and the defendant's testimony at the suppression hearing contradicted the police's version as to whether and how valid consent was obtained for a full search of the vehicle. ${ }^{98}$ Also troubling was proof of the incentive for these officers to trim their testimony because of the way in which asset forfeitures could directly benefit their local police department. ${ }^{99}$

Based upon the totality of the evidence presented, a violation of the Fourth Amendment was found. The officer did not have a proper basis for conducting a traffic stop. The court could not tolerate this evident abuse of the Fourth Amendment. ${ }^{100}$

In United States $v$. Patrick, ${ }^{101}$ the government appealed the district court's decision to suppress statements made by defendant Patrick regarding drug evidence based upon a Fourth Amendment violation. The evidence presented showed that defendant Patrick, a Jamaican, African-American male, walked over the Whirlpool Bridge from Canada to Niagara Falls, New

${ }^{92}$ See id.

${ }^{33} I d$.

st See id.

${ }^{95}$ See id.

${ }^{96}$ See id.

${ }^{97}$ See id.

${ }^{98}$ See id. at 187-88.

${ }^{93}$ See id. at 191.

${ }^{100}$ See id. at 199. In fact, however, the defendant spent many months incarcerated, awaiting disposition of his case. His co-conspirators were found guilty based upon leads furnished by this defendant. The stop was, therefore, from a prosecutorial point of view, successful despite the suppression.

${ }_{101} 899$ F.2d 169 (2d Cir. 1990). 
York. ${ }^{102}$ Just ahead of him, at some distance unclear from the record, walked an African-American female, Linda Taylor. Each was stopped for questioning as they passed by United States Customs Agents. ${ }^{103}$

Both separately explained that they had taken a bus from New York City intending to travel to Niagara Falls, New York. ${ }^{104}$ They claimed they were dropped off on the wrong side of the border and had to walk back. ${ }^{105}$ Nothing in the record indicated that the two were friends or that they were walking or traveling together. ${ }^{106}$ Neither behaved in a suspicious manner while being questioned. ${ }^{107}$

The customs agents sent the travelers to another agent to be searched. ${ }^{108}$ Crack cocaine was found in the woman's bag. ${ }^{109}$ Nothing was found on defendant Patrick. Yet, Patrick was detained, handcuffed to a chair, for approximately four hours and subjected to repeated interrogation. ${ }^{110}$ Finally, after being questioned a number of times by a number of different officers, he admitted to traveling with the woman in order to ensure her delivery of the drugs. ${ }^{111}$

The Court of Appeals reversed the district court's decision to suppress, stating:

Once the Customs officials discovered the cocaine in Taylor's purse, the information they had about Patrick-that he entered the Immigration Office with Taylor at a time when no others were present and that they both had accidentally crossed into Canada-provided an adequate basis for the officials to reasonably believe that Patrick was not just a mere innocent traveling companion but was traveling and acting in concert with Taylor in transporting the cocaine. Therefore, the Customs officials had probable cause to arrest Patrick, and the district court erred in ordering the suppression of the statements he

\footnotetext{
${ }^{102}$ See id. at 170.

${ }^{103}$ See id.

${ }^{104}$ See id.

${ }^{105}$ See id.

${ }^{106}$ See id. at 172 (Weinstein, J., dissenting).

${ }^{107}$ See id. at 173 (Weinstein, J., dissenting).

${ }^{108}$ See id. at 170.

${ }^{109}$ See id.

${ }^{110}$ See id. at 173 (Weinstein, J., dissenting).

${ }^{111}$ See id. (Weinstein, J., dissenting).
} 
made to the law enforcement officials after his arrest. ${ }^{112}$

It seemed clear to the dissenting visiting judge, a co-author of this Article, that in their zeal to prevent drugs from being carried into the United States, the Customs Officers jumped to conclusions, in part, because of race and nationality. He dissented, finding that " $[t]$ he arrest of Christopher Patrick is an example of drug war zealousness infringing on constitutional rights." 113 While not a case dealing with Terry stops, but rather full-scale arrest, it is indicative of the sort of assumption-based policing that often results in the violation of Fourth Amendment rights to privacy and personal security.

\section{CONCLUSION}

The rules established by Terry are not inappropriate. Their recent application, as noted by Professor Maclin, has permitted race-based policing. This country's War on Drugs encourages and facilitates this behavior. It creates tensions within and discriminates against minority communities in a way that is antithetical to the Constitution and to peaceful coexistence.

We should not lose sight of the fact that while the rules governing police conduct in the investigation of crime are not unimportant, there are questions before us that are of greater significance than Terry. There has been enormous change in the last thirty years in our country. The advances in civil rights laws, and the huge increase in the middle class of African American and other ethnic groups has changed the social and economic picture. Nonetheless, it still leaves an unsatisfactory discriminatory racial situation-and as long as we have that underlying situation, we will have the kind of unfairness by the police and in the courts that we have described in this paper.

It is unlikely that the situation will be changed appreciably by means of legal rules that more tightly regulate the police or suppress more evidence in criminal cases. Rather, there are basic substantive law problems that have to be addressed and changed, such as the 100 to 1 ratio used with respect to crack cocaine compared to powder cocaine that has been written into the federal sentencing drug laws.

Another approach is to use emerging technology to promote

\footnotetext{
${ }^{112}$ Id. at 172 .

${ }^{113}$ Id. at 173 (Weinstein, J., dissenting).
} 
non-discriminatory investigatory techniques similar to the airport metal detector which is widely used and, because it is entirely mechanical, does not discriminate against anyone of the basis of their skin color or any other characteristic. It should be noted that such pervasive, non-intrusive searches and surveillance's have their own negative implications. It is uncomfortable to know that "big brother" can keep so many of us under constant surveillance. ${ }^{114}$

These, and others we have mentioned here, are measures that might help in some small way to reduce racism in law enforcement. The simple truth, however, it seems to us, is that so long as we have the basic racial divides in our country, so long as socioeconomic status and access to housing is so racially and ethnically predicated, so long as our children are not brought up in the schools to appreciate each other's cultures, strengths, weaknesses, and to talk to each other, we are going to continue to have the problem of racial discrimination in the administration of justice.

${ }^{114}$ See, e.g., United States v. Riley, 906 F.2d 841, 846 (2d Cir. 1990) (Weinstein, J., dissenting); United States v. Lopex, 328 F. Supp. 1077 (E.D.N.Y. 1971). 
ST. JOHN'S LAW REVIEW

1342 